\title{
Pembentukan Harga Diri: Analisis Presentasi Diri Pelajar SMA di Media Sosial
}

\author{
Alfi Damayanti Sari Nastiti, Dian Purworini \\ Fakultas Ilmu Komunikasi dan Informatika Universitas Muhammadiyah Surakarta \\ alvie.damayanti@gmail.com,dian.purworini@ums.ac.id
}

\begin{abstract}
Self-presentation is a specific action of self-disclosure presenting a positive impression to others. Self-presentation is rapidly growing by the presence of various social media, esppecially Instagram. Instagram as one of social media with a various features and large user, bring major affect to teenager's presentation of self in the media. This is inseparatable part of teenager process in searching their indentity. This research conducted in SMA Negeri Mojogedang by taking sample of 264 students. The data were collected by using questionnaire. It is a descriptive quantitative reaserch which uses factor data analysis. The findings of the research show that self - presentation of teenagers using Instagram media occurs in two phases, the first phase is self-concept creation, students of SMA Negeri Mojogedang try to create their thoughts and feelings in certain ways that refer to themselves as the object. These teenagers want to show their personality to the public. The second phase is self-esteem creation, this phase contains emotional feeling and self-evaluation towards the first concept they have created. Selfconcept that has been created by students of state Senior High School Mojogedang in Instagram can improve their self-presentation that will build their self-esteem. In the reality, it is a fundamental that a teenager wants their presence to be recognized and to be known by public. They try to present themselves widely and passionately by showing a positive image of themselves.
\end{abstract}

Keywords: descriptive quantitative, self-presentation, self-esteem, teenagers.

\begin{abstract}
Abstrak
Presentasi diri merupakan bentuk pengungkapan diri yang spesifik untuk menunjukkan kesan positif dihadapan orang lain. Presentasi diri berkembang pesat dengan kehadiran berbagai media sosial terutama media Instagram. Instagram sebagai salah satu media sosial memberikan ruang yang cukup luas, sehingga dapat mempengaruhi perilaku presentasi diri remaja untuk menunjukkan diri mereka dihadapan khalayak luas. Hal ini tidak terlepas dari masa pencarian jati diri remaja. Penelitian ini dilakukan di SMA Negeri Mojogedang dengan mengambil sampel 264 siswa. Data dikumpulkan dengan menggunakan teknik kuesioner. Penelitian ini memiliki tipe deskriptif kuantitatif menggunakan analisis data faktor analisis.Temuan data menunjukkan jika perilaku presentasi diri remaja di media Instagram terjadi dalam dua fase, fase pertama yaitu pembentukan konsep diri, siswa SMA Negeri Mojogedang berusaha membangun totalitas pemikiran dan perasaan mereka yang mengacu pada diri sendiri sebagai objek dimana pelaku ingin memperlihatkan kepribadian mereka dihadapan khalayak luas. dan fase kedua yaitu membentuk harga diri, pada fase ini merupakan bentuk emosionnal dan evaluasi diri siswa pada konsep yang telah mereka buat. Konsep diri yang telah dibangun oleh siswa SMA Negeri Mojogedang di dalam media Instagram dapat meningkatkan perilaku presentasi diri mereka yang akan membentuk harga diri remaja tersebut. Karena
\end{abstract}


pada dasarnya seorang remaja ingin diakui keberadaan mereka dihadapan khalayak luas, kemudian mereka berusaha menampilkan diri mereka secara luas dan mendalam dengan menunjukkan citra positif dalam diri mereka.

Kata Kunci: deskriptif kuantitatif, harga diri, presentasi diri, remaja

\section{Pendahuluan}

Setiap individu terutama kalangan remaja memiliki berbagai macam cara dalam melakukan presentasi diri, salah satunya melalui media sosial instagram. Pengguna media sosial selalu berusaha menampilkan diri mereka dengan cara mengupdate status pada halaman akun mereka, menyampaikan kritikan kepada orang lain atau pengguna lain, kemudian menyampaikan kondisi pribadi dan aktivitas yang saat ini dilakukannya. Melalui fasilitas foto, tulisan atau video bahkan berbagi lokasi, presentasi diri seolah menjadi hal penting dan menarik bagi remaja, apalagi didukung dengan berbagai aplikasi seperti adobe photoshop, camera 360, plastic surgery, dan beauty plus magical camera, dll.

Bullingham \& Vasconcelos (2013) mengatakan bahwa dari studi Erving Goffman, presentasi diri merupakan sebuah analisis dari interaksi interpersonal dan upaya seseorang memproyeksikan visual sosok diri yang ingin ditampilkan dalam sebuah panggung yang menampilkan sisi depan dan belakang. Ketika berada di depan panggung, seseorang memainkan peran yang sudah ditentukan dan kembali menjadi diri sendiri ketika berada di panggung belakang.

Konsep dari presentasi diri yang sebenarnya adalah manajemen kesan, dimana setiap individu berusaha untuk menciptakan kesan positif dihadapan orang lain (Zarghooni, 2007). Individu berusaha untuk menyampaikan tentang diri mereka kepada orang lain bahwa mereka adalah tipe orang tertentu yang mempunyai karakteristik tertentu, dengan mempresentasikan diri mereka secara sadar untuk mencapai tujuan yang diinginkan.

Contohnya ketika seorang pelajar mempresentasikan diri pada media instagram, dia dapat menampilkan dirinya sesuai dengan keinginannya dengan tujuan untuk membangun hubungan dengan pengguna lain. sehingga mereka sengaja menyusun citra positif untuk mengungkapkan sisi dirinya secara luas, lebih mendalam dan otentik melalui media sosial Instagram. Hal ini sebagai kontrol wilayah depan, yang mengendalikan perilaku seseorang sesuai dengan wilayah depan yang ada. Namun, ketika mereka kembali kedunia nyata yang mana mereka berada dibelakang panggung, dia harus kembali ke rutinitasnya sebagai seorang pelajar.

Goffman (1956) mengatakan bahwa pelaku atau seorang aktor berinteraksi kepada penonton ketika berada diwilayah depan. Perilaku dipanggung depan mencerminkan harapan dan norma yang terinternalisasi untuk perilaku remaja yang telah dibentuk dari peran khusus yang telah dimainkan dan penampilan fisik mereka. Instagram merupakan panggung depan dari presentasi diri di internet, konsep diri remaja dibentuk melalui media internet, dimana ketika berada di Instagram seorang remaja menciptakan diri ideal dan bukan diri yang realistis. 
Alfi Damayanti Sari Nastiti, Dian Purworini : Pembentukan Harga Diri: Analisis Presentasi Diri Pelajar SMA di Media Sosial

Penerapan panggung depan dan belakang dalam instagram yaitu, pada halaman beranda ( homepage) dan pencarian ( serch) merupakan panggung depan, dimana pengguna dapat mempresentasikan diri mereka dengan baik dan melihat postingan pengguna lain, sedangkan interaksi seperti pesan pribadi yang dikirim antar pengguna, mengedit foto maupun video menggunakan filter yang tersedia merupakan panggung belakang mereka.

Penelitian yang dilakukan oleh Eri Husna Permata pada tahun 2017 yang meneliti tentang, Hubungan Penggunaan Media Instagram dengan Presentasi Diri Pada Kalangan Mahasiswa Ilmu Komunikasi UNITIRTA. Menggunakan teori perbedaan individu dengan metode pendekatan kuantitatif, hasil dari penelitian ini adalah terdapat suatu hubungan dalam penggunaan media sosial instagram dengan presentasi diri pada Mahasiswa sebesar 0,719. Yang berbarti bahwa hubungan antara variabel $\mathrm{X}$ dan $\mathrm{Y}$ adalah hubungan yang sangat kuat karena nilainya berkisar antara 0,60 - 0,799 (Permata, 2017).

Sherman, Payton, Hernandez, Greenfield, \& Dapretto (2016) mengatakan bahwa remaja mengunggah foto diri ( selfi ) mereka di media sosial instagram dengan tujuan untuk mendapatkan respon berupa ( like ) dari pengguna lainnya. Mereka meyakini bahwa respon yang paling sering mereka dapatkan adalah dari teman sebayanya. Semakin banyak like yang didapatkan, maka semakin banyak pula foto yang diunggah dapat dikatakan sebagai foto terpopuler. Namun sebaliknya, apabila foto yang tidak mendapatkan like terlalu banyak, maka dianggap foto tersebut kurang menarik dan tidak populer. Kepopuleran sebuah foto akan berdampak bagi presentasi diri dan kepercayaan diri mereka.

Fardouly, Willburger, \& Vertanian (2017) mengatakan bahwa melalui dua cara instagram dapat mempengaruhi citra tubuh dan self-objectification dalam kalangan remaja Diantaranya, yang pertama Instagram adalam platform media sosial yang berbasis gambar dan setiap harinya telah diunggah gambar lebih dari 80 juta gambar, yang kemudian memberikan kesempatan bagi pengguna terutama remaja untuk membandingkan penampilan mereka dengan pengguna lain. Yang kedua karena pengguna sering mengedit dan meningkatkan citra mereka melalui filter yang disediakan dalam media instagram sebelum memasang pada profil mereka. Gambar di instagram dapat mempromosikan cita-cita kecantikan pengguna dan juga berakibat bagi pengguna menilai diri asli mereka kurang menarik dibandingkan pengguna lain di instagram.

Media sosial dijelaskan dalam teori SME (Social Media Engagement) adalah suatu evolusi teknologi untuk memberikan pengalaman unik bagi pengguna dengan cara baru yang sebelumnya belum pernah dilakukan. Dalam teori ini mendefinisikan pengalaman sebagai kata benda, pada konten yang berasal dari partisipasi langsung (Gangi \& Wasko, 2016). Penelitian yang dilakukan oleh (Kinanti \& Putri, 2017) terhadap akun instagram @zapcoid menunjukkan jika akun tersebut memiliki pengaruh signifikan terhadap brand equity. Adapun indicator paling tinggi dari instagram tersebut, didapatkan dari context, connection, communication dan paling rendah adalah collaboration.

Media sosial unggul dalam memberikan kecepatan informasi sehingga membuat penggunanya semakin dinamis dan adaptif (Purworini, 2012). Dalam media sosial instagram kebanyakan mahasiswa melakukan presentasi diri dengan 
cara mengubah bentuk diri atau mempercantik foto dan bahkan ada yang menuliskan identitas berbeda dari aslinya untuk mendapatkan kesan yang mereka inginkan (Michikyan, Dennis, \& Subrahmanyam, 2015) .

Dari data Asosiasi Penyelenggara Jasa Internet Indonesia (APJII) tahun 2016, jumlah remaja yang menggunakan internet di Indonesia 18,4\%. Jumlah ini ketiga dari keseluruhan total pengguna di indonesia. Kemudian jumlah pengguna instagram menduduki peringkat kedua setelah facebook sebesar 15\%. Hal ini membuktikan bahwa eksistensi media sosial instagram sangatlah tinggi dikalangan masyarakat luas terutama pada remaja.

Media instagram adalah salah satu bentuk budaya komunikasi baru, ketika teks tidak lagi menjadi prioritas utama dalam penyampaian pesan, melainkan gambar. Gambar menjadi unsur penting dalam menceritakan atau menyampaikan informasi kepada khalayak luas (Al-kandari, Melkote, \& Sharif, 2016).

Presentasi diri dapat membahayakan diri seseorang jika tidak dikontrol dengan baik. Berbagai masalah dialami oleh seseorang yang berlebihan dalam melakukan presentasi diri. Diantaranya yaitu seorang siswa dari Rizal High School, Filipina terjatuh dari tangga sekolah akibat selfi bersama temannya pada jam istirahat sekolah (Liputan6.com, 5 juli 2014). Lima remaja asal Madiun mengalami kecelakaan tersambar kereta setelah melakukan foto selfi yang berlatar belakang rel kereta api (TribunNews.com, 23 Februari 2015). Danny Bowman remaja asal Newcastel Inggris, nyaris akan melakukan bunuh diri akibat frustasi dari melakukan selfi. Remaja tersebut mengalami overdosis dan kecanduan melakukan selfi, setiap hari nya dia mengambil foto selfi sebanyak 200 foto dan dia merasa dari sekian banyak foto selfi nya tak satupun yang sesuai dengan keinginan nya ( Kompas.com, 24 maret 2014). Triana Lavey wanita berkebangsaan Amerika Serikat ini telah menghabiskan uang nya sebanyak 175 juta untuk melakukan operasi plastik demi mendapatkan wajah yang sempurna untuk melakukan foto selfi (Okezone.com, 26 April 2014).

Mencermati potensi bahaya tersebut, berbagai penelitian tentang presentasi diri di media sosial telah banyak dilakukan. Diantaranya yaitu oleh (Yang \& Brown, 2016), (Bullingham \& Vasconcelos, 2013) dan (Permata, 2017). Penelitian ini ingin menganalisis presentasi diri di kalangan remaja SMA Negeri Mojogedang. SMA ini berlokasi di kabupaten Karanganyar yang jauh dari keramaian kota. Dengan demikian penelitian ini menarik untuk dilakukan, karena menunjukkan apakah remaja di kota kecil juga memerlukan presentasi diri untuk mendapatkan penerimaan diri dari khalayak luas.

Tujuan penelitian dilakukan adalah untuk mengetahui aktifitas yang dilakukan remaja terutama siswa SMA Negeri Mojogedang dalam melakukan presentasi diri pada media sosial instagram. Perbedaan penelitian ini dengan yang lainnya adalah, bahwa peneliti ingin mengetahui pola perilaku remaja di dalam media instagram sebagai wadah untuk mempresentasikan diri, menggunakan teori Dramaturgi dari Erving Goffman dengan metode deskriptif kuantitatif. 
Alfi Damayanti Sari Nastiti, Dian Purworini : Pembentukan Harga Diri: Analisis Presentasi Diri Pelajar SMA di Media Sosial

\section{Metode Penelitian}

Sesuai dengan tujuan penelitian, maka penelitian ini menggunakan tipe penelitian deskriptif kuantitatif. Tujuan metode deskriptif kuantitatif untuk mendeskripsikan tentang perilaku remaja khususnya siswa SMA Negeri Mojogedang dalam mempresentasikan dirinya di media sosial Instagram. Alasan memilih siswa SMA yaitu, remaja pada masa kini memanfaatkan media sosial terutama Instagram sebagai sarana untuk mempresentasikan diri, mereka berusaha mengontrol diri mereka dari segi penampilan fisik dan perilaku aktual ketika menjalankan peran nya di atas panggung. Instagram menuntut remaja untuk selalu mengunggah foto mereka atau memposting seluruh kegiatan mereka dalam sebuah fitur story yang telah disediakan. Instagram dijadikan sebagai rumah bagi remaja dengan mengungkapkan perasaan mereka dalam bentuk foto atau video yang diunggahnya.

Data didapatkan melalui pengumpulan data dalam bentuk kuesioner Kuesioner yang digunakan diadopsi dari jurnal dari Chia-chen Yang dan B.Bradford Brown, yang berjudul Online Self-Presentation on Facebook and Self Development During the College Transition. Dalam jurnal ini presentasi diri dianalisis dengan memperhatikan dimensi yang biasanya dinilai dalam penelitian pengungkapan diri, yaitu mencangkup keluasan ( jumlah informasi yang disajikan ), kedalaman ( tingkat keintiman informasi yang disajikan ), positif ( valensi informasi ), keaslian ( tingkat presentasi yang akurat mencerminkan pengguna ), dan intensionalitas (sejauh mana individu secara sadar dan sengaja mengungkapkan sepotong informasi dirinya ). Kemudian luas, kedalaman dan keaslian presentasi diri akan dikaitkan dengan umpan balik ( feedback) yang lebih mendukung dari penonton. Setelah itu, umpan balik yang didukung pada gilirannya akan terkait dengan kejelasan konsep diri dan harga diri yang tinggi (Yang \& Brown, 2016).

Sebelum menentukan sampel, peneliti melakukan pengukuran sampel. Hal ini dimaksudkan agar besarnya pengambilan sampel dapat terarah. Pengukuran sampel menggunakan rumus Yamane yaitu, $N=\frac{N}{N d^{2}+1}$ misalnya, peneliti ingin menduga perilaku remaja dalam presentasi diri di media instagram dari populasi 880 siswa. Angka 5\% adalah presisi yang telah ditetapkan dari tingkat kepercayaan yang bernilai 95\%, maka besar sampel yaitu: $N=\frac{880}{880 X(0,05)^{2}+1}=275$, hasil perhitungan dari rumus Yamane sebesar 275, maka dapat dijadikan sebagai ukuran pengambilan sampel sebesar 275 siswa atau mendekati itu. Menurut Kriantono (2006) mengatakan bahwa tidak ada ukuran sampel pasti dari banyak periset.

Pengambilan sampel dalam penelitian ini menggunakan teknik stratified sampling atau sampling berstrata. Dalam teknik ini, populasi dikelompokkan ke dalam kelompok atau kategori yang disebut strata.sampel ini bertujuan untuk mengubah sifat populasi yang heterogen menjadi bersifat homogen. Artinya suatu populasi yang dianggap heterogen dikelompokkan kedalam subpopulasi berdasarkan karakteristik tertentu, sehingga setiap strata mempunyai anggota sampel yang relatif homogen. Setelah menghitung pengukuran sampel, dapat 
diketahui bahwa presentase jumlah sampel yang harus diambil sebesar $30 \%$ dari jumlah populasi.

Tabel 1. Pengambilan sampel kelas

\begin{tabular}{ccc}
\hline Strata kelas & $\begin{array}{c}\text { Jumlah } \\
\text { anggota }\end{array}$ & $\begin{array}{c}\text { Jumlah Objek yang diambil } \\
\text { Proporsional (30\%) }\end{array}$ \\
\hline 1 & 324 & 97 \\
2 & 210 & 63 \\
3 & 346 & 104 \\
Jumlah & 880 & 264 \\
\hline
\end{tabular}

Sumber: Data jumlah siswa SMA Negeri Mojogedang tahun ajaran 2017/2018.

Metode analisis data menggunakan analisis statistik deskriptif. Statistik deskriptif digunakan untuk menggambarkan peristiwa, perilaku atau objek lain. Hasil dari perhitungan analisis deskriptif ini nantinya akan menjadi dasar bagi perhitungan analisis berikutnya. Peneliti menggunakan skala likert yang dapat digunakan untuk mengukur persepsi tentang suatu fenomena tertentu, pendapat, sikap dan perilaku.

Beberapa indikator yang sudah didapatkan akan diukur dengan validitas dan reabilitasnya, menggunakan faktor analisis dengan cara Principal Component Analysis (PCA) yang akan dihitung menggunakan aplikasi SPSS. Menurut Woodward \& Hunter (2015), PCA adalah teknik untuk menyederhanakan data variabel awal menjadi variabel baru yang lebih kecil jumlahnya. Dalam teknik ini variabel awal masih terbentuk dalam variabel latin dan belum ditentukan teori dan hipotesisnya. Sehingga PCA dapat digunakan untuk membangun teori dan konsep baru. Berbeda dengan CFA, PCA tidak membedakan varian umum dan khusus. Namun membagi semua varian dalam matrik korelasi dengan matrik pola faktor. Faktor yang menjelaskan proporsi varians tertinggi adalah variabel yang mewakili konstruksi yang mendasarinya. Salah satu penggunaan tersebut adalah untuk menyederhanakan analisis regresi dengan mengurangi variabel prediktor.

\section{Hasil Penemuan dan Diskusi}

Penelitian ini dilakukan pada tanggal 24 Oktober 2017 di SMA Negeri Mojogedang, yang berlokasi di kecamatan Mojogedang, kabupaten Karanganyar, provinsi Jawa tengah. Peneliti menggunakan sampel sebanyak 264 peserta, berdasarkan hasil kuesioner $80 \%$ dari mereka telah menggunakan Instagram selama 3 tahun dan 20\% lainnya menggunakan Instagram hanya dalam waktu kurang dari 1 tahun.

Faktor analisis dapat digunakan untuk mereduksi dimensi suatu data tanpa harus mengurangi karakteristik data tersebut secara signifikan. Faktor yang dapat menjelaskan proporsi varian tertinggi adalah variabel yang mewakili konstruksi yang mendasarinya. 
Alfi Damayanti Sari Nastiti, Dian Purworini : Pembentukan Harga Diri: Analisis Presentasi Diri Pelajar SMA di Media Sosial

Data yang digunakan dalam analisis faktor berdasarkan dari pendapat responden mengenai faktor presentasi diri di media sosial Instagram. Berdasarkan hal tersebut maka perlu dianalisis lebih lanjut indikator - indikator yang mendasari presentasi diri di Instagram, indikator tersebut antara lain: Breadth (keluasan jumlah informasi yang disajikan), Depth (kedalaman tingkat keintiman informasi yang disajikan), Positivity (positif valensi informasi), Authenticity (keaslian tingkat presentasi yang akurat mencerminkan pengguna), Intensionality (intensionalitas sejauh mana individu secara sadar dan sengaja mengungkapkan sepotong informasi dirinya), feedback (umpan balik yang didapatkan), self reflection (reflaksi diri yang diterima), sellf-esteem (harga diri), dan self- concept clarity (kejelasan konsep yang sudah dibentuk). Keseluruhan indikator tersebut dapat dijadikan sebagai varian yang akan dianalisis menggunakan faktor analisis PCA dengan bantuan program komputer SPSS 16 (Statistical Product and Service Solution).

Uji Kaiser Mayer Olkin (KMO) digunakan untuk menentukan layak atau tidak faktor analisis dilakukan. Nilai indeks KMO yang berkisar antara 0,5 sampai 1 menjadi persyaratan pokok yang harus dipenuhi. Besarnya nilai KMO dapat dilihat pada tabel 2.

Tabel 2. Uji KMO

\begin{tabular}{ll}
\hline Uji KMO dan Bartlett's & Hasil Penelitian \\
\hline KMO Measure of Sampling & 0,816 \\
Adequacy & - \\
Bartlett's Test of Sphericity & 534,619 \\
Approx. Chi-Square & 36 \\
Derajat Kebebasan ( Df ) & 0,000 \\
Signifikansi ( sig ) & \\
\hline
\end{tabular}

Sumber : Hasil KMO (Kaiser Mayer Olkin ) Measure of Sampling Adequacy and Bartlett's Test.

Berdasakan hasil analisis menggunakan SPSS 16 telah diperoleh angka KMO Measure of Sampling Adequacy sebesar 0,816 dengan signifikansi ( sig ) sebesar 0,000 . Varian data dapat dianalisis lebih lanjut karena, angka 0,816 berada diatas 0,5 dan signifikansi ( sig ) 0,000 yang berarti lebih kecil dari 0,05. Dari data siswa diatas diperoleh nilai yang ideal, maka langkah selanjutnya melakukan perhitungan MSA.

Besarnya MSA (Measure of Sampling Adequacy) merupakan uji statistik yang digunakan untuk mengetahui korelasi antar indikator. Besarnya angka MSA (Measure of Sampling Adequacy ) adalah 0 sampai 1, jika digunakan dalam menentukan penggabungan varian ketentuannya sebagai berikut:

- Suatu varian dapat diprediksi tanpa kesalahan apabila nilai MSA = 1 .

- Suatu varian dapat diprediksi dan dapat dianalisis lebih lanjut Jika MSA $\geq$ 0,5 .

- Jika MSA $\leq 0,5$ maka varian tersebut tidak dapat diprediksi dn tidak dapat dianalisis lebih lanjut sehingga indikator tersebut harus dikeluarkan. 
Besarnya MSA masing - masing indikator dalam penelitian ini dapat dilihat pada tabel 3.

Tabel 3. Uji MSA

\begin{tabular}{ccc}
\hline NO & Indikator - Indikator & MSA \\
\hline 1 & Breadth of Instagram self- presentation & 0,807 \\
2 & Depth of Instagram self- presentation & 0,806 \\
3 & Positivity of Instagram self- presentation & 0,835 \\
4 & Authenticity of Instagram self- presentation & 0,839 \\
5 & Intensionality of Instagram self- presentation & 0,805 \\
6 & Audience supportive feedback & 0,790 \\
7 & Self - Refleksion of Instagram self- presentation & 0,885 \\
8 & Self - esteem of Instagram self- presentation & 0,796 \\
9 & Self - concept clarity of Instagram self- presentation & 0,789 \\
\hline
\end{tabular}

Sumber : SPSS 16 - Analisis data primer, 2017

Dari hasil perhitungan diatas dapat diketahui bahwa keseluruhan indikator tersebut mempunyai hubungan yang sangat erat, maka dapat disimpulkan melalui perhitungan MSA perilaku siswa di media Instagram telah muncul. Kemudian dapat melakukan analisis lebih lanjut karena nilai MSA yang didapatkan lebih besar dari 0,5. Banyaknya faktor yang mungkin akan terbentuk dapat ditentukan menggunakan tabel 4.

Tabel 4. Total variance explained

\begin{tabular}{|c|c|c|c|c|c|c|c|c|c|}
\hline \multirow[b]{2}{*}{$\begin{array}{c}\text { compo } \\
\text { nent }\end{array}$} & \multicolumn{3}{|c|}{ Initial eigenvalues } & \multicolumn{3}{|c|}{$\begin{array}{l}\text { Extraction sums of } \\
\text { squared loading }\end{array}$} & \multicolumn{3}{|c|}{$\begin{array}{l}\text { Rotation sums of squared } \\
\text { loading }\end{array}$} \\
\hline & Total & $\begin{array}{c}\% \text { of } \\
\text { varian } \\
\text { ce }\end{array}$ & $\begin{array}{c}\text { Cumulati } \\
\text { ve } \%\end{array}$ & Total & $\begin{array}{c}\% \text { of } \\
\text { varian } \\
\text { ce }\end{array}$ & $\begin{array}{l}\text { Cumulati } \\
\text { ve } \%\end{array}$ & Total & $\begin{array}{c}\% \text { of } \\
\text { varian } \\
\text { ce }\end{array}$ & $\begin{array}{l}\text { Cumulati } \\
\text { ve } \%\end{array}$ \\
\hline 1 & 3,414 & 37,930 & 37,930 & $\begin{array}{r}3,41 \\
4\end{array}$ & $\begin{array}{r}37,93 \\
0\end{array}$ & 37,930 & 2,305 & 25,615 & 25,615 \\
\hline 2 & 1,074 & 11,938 & 49,868 & $\begin{array}{r}1,07 \\
4\end{array}$ & $\begin{array}{r}11,93 \\
8\end{array}$ & 49,868 & 2,183 & 24,254 & 49,868 \\
\hline $\begin{array}{l}3 \\
4\end{array}$ & $\begin{array}{l}.972 \\
.820\end{array}$ & $\begin{array}{r}10,798 \\
9,110\end{array}$ & $\begin{array}{l}60,666 \\
69,776\end{array}$ & & & & & & \\
\hline 5 & ,738 & 8,196 & 77,972 & & & & & & \\
\hline 6 & ,565 & 6,275 & 84,248 & & & & & & \\
\hline 7 & ,527, & 5,853 & 90,101 & & & & & & \\
\hline 8 & 462 & 5,138 & 95,238 & & & & & & \\
\hline 9 & ,429 & 4,762 & 100,000 & & & & & & \\
\hline
\end{tabular}

Sumber : Extraction Method principal component analysis, SPSS 16

Pada tabel di atas, menjelaskan bahwa nilai yang paling tinggi atau lebih dari 1 dapat menjadi faktor utama pembentuk perilaku siswa di media Instagram. jumlah variabel independen dapat diwakili oleh componen yang berkisar antara 1 hingga 9. Jumlah total yang bernilai 1 yaitu pada varians yang diterangkan pada faktor 1 adalah $3,414 / 9 \times 100 \%=37,930$ kemudian oleh faktor 2 adala 1,074/9 $\times$ 
Alfi Damayanti Sari Nastiti, Dian Purworini : Pembentukan Harga Diri: Analisis Presentasi Diri Pelajar SMA di Media Sosial

$100 \%=11,938$. kemudian total kedua faktor tersebut mampu menjelaskan variabel sebesar 37,930 $+11,938=49,868$. Dengan demikian dapat disimpulkan bahwa nilai eigenvalues yang ditetapkan 1, maka nilai total yang dapat diambil untuk mewakili faktor maksimal yang menjelaskan variabel harus $>1$ yaitu component 1 dan 2 . Untuk memperjelas lagi dapat dilihat menggunakan tabel $5 \mathrm{di}$ bawah ini.

Tabel 5. Rotated component matrix

\begin{tabular}{lcc}
\hline & \multicolumn{2}{c}{ Component } \\
& 1 & 2 \\
\hline Breadth &, 236 &, 722 \\
Depth &, 133 &, 666 \\
Positivity &, 500 &, 394 \\
Authenticity &, 720 &, 197 \\
Intensionality &, 780 &, 135 \\
Audience supportive feedback &, 137 &, 708 \\
Self - Refleksion &, 479 &, 359 \\
Self - esteem & .186 &, 604 \\
Self - concept clarity &, 756 &, 111 \\
\hline
\end{tabular}

Sumber: extraction method principal component analysis SPSS 16

Rotation method: varimax with kaiser normalization.

a. Rotation converged in 3 iterations.

Tabel diatas merupakan perhitungan akhir untuk penentuan input variabel ke dalam faktor tertentu mengikuti pada besaran korelasi antar variabel dengan faktor, yaitu besar korelasi yang cukup kuat lebih dari 0,5. Dengan demikian maka faktor dan variabel anggotanya adalah:

- Faktor 1 (Positivity, Authenticity, intensionality, self - concept clarity)

- Faktor 2 (Breadth, Depth, Audience supportive feedback,Self - esteem)

Dari tabel diatas sudah sangat terlihat bahwa adanya perilaku siswa SMA Negeri Mojogedang dalam mempresentasikan diri mereka melalui dua tahap, kedua tahap tersebut akan dijelaskan pada tabel 6,component transformation matrix dibawah ini:

Tabel 6. Rotation method: varimax with kaiser normalization.

\begin{tabular}{lll}
\hline Component & 1 & 2 \\
1 &, 725 &, 688 \\
2 &,- 688 &, 725 \\
\hline
\end{tabular}

Sumber : extraction method principal component analysis SPSS 16

Pada tabel diatas menunjukkan bahwa faktor 1 maupun faktor 2 samasama memiliki korelasi sebesar 0,725 hal ini berarti bahwa hubungan kedua faktor tersebut cukup kuat karena mempunyai nilai lebih besar dari 0,5. Dengan demikian faktor 1 dan faktor 2 dapat merangkum keseluruhan variabel independen. Dari analisis tersebut dapat disimpulkan bahwa terbentuk dua faktor dalam perilaku presentasi siswa SMA Negeri Mojogedang yaitu: faktor 1 terdiri atas variabel independen diantaranya positivity, Authenticity, Intensionality, dan 
self - concept clarity. Faktor pertama dapat disebut juga sebagai fase pertama seorang remaja melakukan presentasi diri.

Teori Dramaturgi dijelaskan bahwa seorang aktor berhak memilih peran yang akan dipentaskan di atas panggung, dalam fase ini seorang remaja berusaha untuk menentukan konsep diri mereka sebelum mempresentasikan diri mereka di media Instagram. Melalui fase pertama ini dapat dideskripsikan perilaku remaja di media Instagram untuk mempresentasikan dirinya dengan bersikap positif dan menunjukkan diri mereka kepada khalayak luas, pada fase ini remaja dengan kesadaran mereka ingin memperkenalkan diri mereka kepada khalayak luas melalui media Instagram, untuk membentuk konsep diri mereka pada media sosial atau media internet.

Faktor 2 terdiri atas variabel independen diantarany Breadth, Depth, Audience supportive feedback, dan sel-esteem. Pada faktor ke 2 dapat disebut sebagai fase kedua atau fase selanjutnya remaja dalam mempresentasikan diri mereka. Kelanjutan teori Dramaturgi juga menjelaskan bahwa, ketika seorang aktor telah berada diatas panggung, maka dia harus memerankan peran yang telah dipilihnya.

Dalam fase ini remaja telah memiliki konsep diri yang akan mereka tunjukkan di media Instagram, kemudian mereka berperilaku seolah - olah berusaha mempertahankan peran yang telah dimilikinya dengan cara memperluas dan mendalami peran tersebut. hingga mereka mendapatkan sebuah feedback atau umpan balik dari pengguna lain. Tidak hanya menerima, namun remaja yang menggunakan Instagram dapat pula memberikan umpan balik berupa kritikan atau pujian kepada sesama pengguna lain. Umpan balik yang mereka dapatkan adalah sebuah motivasi atau support bagi seorang remaja untuk meningkatkan presentasi diri mereka di media sosial Instagram. Dukungan yang mereka dapatkan akan membentuk harga diri mereka di media Internet.

\section{Diskusi}

Berdasarkan hasil penelitian diatas, maka peneliti dapat menyampaikan beberapa temuan dalam penelitian tersebut bahwa perilaku presentasi diri remaja yaitu siswa SMA Negeri Mojogedang di media Instagram terjadi dua fase. Fase pertama yaitu pembangunan konsep diri dan fase kedua merupakan fase akhir dari perilaku presentasi diri yang membentuk harga diri remaja. Dalam pembahasan ini akan diulas satu per satu mengenai kedua fase tersebut.

\section{Fase pertama: Pembangunan konsep diri}

Pada fase pertama yaitu pembentukan konsep diri. Dalam hal ini remaja secara sadar ingin memperkenalkan diri mereka dihadapan khalayak luas. pada tabel 5 komponen Intensionallty memiliki nilai sebesar 780 jika dipersentasekan sebesar $(7,80 \%)$ merupakan nilai tertinggi. Hal ini menunjukkan jika remaja mempunyai keinginan yang sangat kuat dan otentik untuk memperkenalkan diri mereka melalui media Instagram.

Dengan menggambarkan diri mereka yang populer, berpengetahuan luas, dan bijaksana dengan mengunggah foto remaja tersebut, atau mengunggah video aktfitas keseharian mereka (Vogel \& Rose, 2016). Jadi seorang remaja memiliki 
Alfi Damayanti Sari Nastiti, Dian Purworini : Pembentukan Harga Diri: Analisis Presentasi Diri Pelajar SMA di Media Sosial

kesadaran yang sangat tinggi dalam melakukan presentasi diri untuk membangun hubungan dengan orang lain. Namun pada fase pertama, remaja tidak terlalu fokus pada penerima informasi tentang diri mereka yang mereka tampilkan di media Instagram. Mereka hanya berfokus pada kesadaran mereka untuk mmemperkenalkan diri kepada khalayak luas. Terlihat pada tabel 5 bahwa valensi informasi ( positivity) memiliki nilai 500 jika dipersentasekan sebesar 5\%, yang merupakan angka terendah dalam fase pertama.

Konsep diri dapat didefinisikan sebagai totalitas pemikiran dan perasaan individu yang mengacu pada diri sendiri sebagai objek, dimana didalamnya pelaku ingin memperlihatkan kepribadian mereka dihadapan khalayak luas (Fullwood, James, \& Chen-wilson, 2016). Seorang remaja berusaha membangun indentitas diri mereka dimedia sosial Instagram. Remaja yang memiliki konsep diri yang rendah, akan memiliki harga diri yang rendah pula. Sebaliknya, ketika seorang remaja memiliki kejelasan konsep diri yang tinggi, maka akan memiliki harga diri yang tinggi pula. Pembangunan konsep diri remaja akan berpengaruh bagi harga diri mereka. Kebanyakan remaja yang melakukan presentasi diri di media sosial memiliki kejelasan konsep yang rendah pada kehidupan nyata, maka melalui media sosial mereka membangun kembali konsep diri mereka.

\section{Fase kedua: Pembentukan harga diri remaja}

Perilaku presentasi diri remaja di Instagram dilanjutkan pada fase kedua, dalam fase ini remaja berusaha untuk menciptakan harga diri mereka di hadapan khalayak luas yang ingin mengetahui siapa diri mereka yang sebenarnya. Ketika seorang remaja telah berhasil membangun konsep diri mereka di media Instagram dengan cara mengunggah foto maupun video aktifitas mereka, kemudian mereka berusaha mempertahankan konsep diri yang telah terbentuk dengan cara memperluas perilaku presentasi diri mereka di media Instagram, dengan memposting foto - foto mereka secara berkala, kemudian mereka juga menginformasikan aktifitas keseharian mereka secara rutin di fitur story baik dalam bentuk foto ataupun video pada media Instagram. Hal ini dapat dilihat pada tabel 5 bahwa breadth memiliki nilai 722 apabila dipersentasekan sebesar ( 7,22\% ) yang menunjukkan nilai tertinggi. Dimana jumlah informasi yang disajikan remaja dalam media Instagram selalu bertambah dari hari ke hari. Jadi melalui tabel diatas dapat dikatakan bahwa remaja sangat aktif melakukan presentasi diri di media Instagram.

Menurut Yang \& Brown (2016) bahwa, pada saat remaja telah berhasil membangun konsep diri, yang berupa penerimaan diri yang jelas di hadapan khalak luas, maka media sosial Instagram memberikan kesempatan kepada mereka untuk mengeksplorasi siapa mereka dan apa yang mereka inginkan dengan cara memperluas informasi diri. Pada tahap inilah perilaku remaja terbentuk, terjadinya komunikasi dalam media sosial ketika remaja mendapatkan umpan balik ( feedback ) dari pengguna lain berupa like atau komentar pada postingan mereka. Kritikan dan saran yang mereka dapatkan dari pengguna lain akan dijadikan sebagai motivasi bagi remaja untuk terus meningkatkan presentasi diri mereka. Pada tabel diatas digambarkan bahwa tingkat keintiman informasi yang disajikan ( depth ) memiliki nilai terendah yaitu 666 persentase yang diperoleh sebesar ( 
$6,66 \%$ ). Hal ini dapat diartikan bahwa seorang remaja hanya berusaha memperkenalkan dirinya, namun belum mampu memberikan informasi secara mendalam mengenai diri mereka pada khalayak luas.

Al-kandari et al (2016) menjelaskan bahwa, individu pada usia remaja berusaha untuk mengungkapkan diri mereka demi mendapatkan pengakuan akan status dirinya dan mengeksplorasi diri dengan membangun citra positif mereka. Konsep diri yang telah dibangun seorang individu atau remaja didalam media sosial dapat meningkatkan perilaku presentasi diri remaja yang akan membentuk harga diri remaja tersebut, hal ini dapat dijadikan bagian yang paling menarik dari penelitian yang telah dilakukan.

Remaja berusaha membangun konsep diri dengan mengunggah foto terbaik mereka di media Instagram, mereka secara sadar memperkenalkan diri mereka dihadapan publik dengan menuliskan beberapa caption atau keterangan pada foto yang telah mereka posting. Dalam hal ini konsep diri dapat diartikan ciri kepribadian, kecantikan fisik yang dimiliki setiap remaja sehingga mereka mendapatkan penerimaan sosial dari khalayak luas.

Kemudian harga diri dapat diartikan sebagai sisi emosional dan evaluasi diri seorang remaja pada konsep diri yang telah mereka buat. Untuk membangun harga diri, diperlukan sebuah presentasi diri yang didalamnya, remaja dapat mengungkapkan diri mereka dihadapan khalayak luas. presentasi diri adalah wujud perilaku remaja yang disampaikan kepada orang lain. Harga diri mengacu pada evaluasi diri atau penilaian seseorang terhadap diri sendiri, yaitu sejauh mana seseorang menganggap diri sebagai orang yang layak dan kompeten. Harga diri adalah perluasan dari konsep diri yang menyajikan berbagai fungsi sosial dan eksistensial (Vogel \& Rose, 2016). Harga diri seorang remaja dapat dikonseptualisasikan sebagai sifat yang stabil dan berkembang dari waktu ke waktu dalam keadaan yang responsif terhadap kejadian dan konteks sehari-hari.

Temuan lain dari penelitian ini adalah bahwa presentasi diri dimedia sosial Instagram dapat terjadi apabila seorang remaja memiliki konsep diri yang rendah dalam dunia nyatanya. Mereka berusaha untuk membangun kembali konsep diri mereka melalui media sosial Instagram, dengan cara memposting berbagai kegiatan mereka sehari-hari dalam bentuk foto maupun video. Perilaku presentasi diri dapat terlihat dari aktifitas yang sudah mereka lakukan pada media Instagram. Kemudian presentasi diri inilah yang membentuk harga diri mereka yang lebih besar.

Berbeda dengan penelitian lain, yang ditulis oleh Yang \& Brown (2016), temuan dalam penelitian tersebut adalah penggunaan situs jejaring sosial dimediasi oleh umpan balik yang diterima mahasiswa dari teman facebook. Pengguna facebook cenderung meyakini bahwa komentar yang mereka dapatkan merupakan bentuk "suka" dari pengguna lain atau teman mereka. Sehingga mereka dapat memperbarui halaman facebook mereka secara terus menerus. Dalam penelitian ini ditegaskan bahwa pengembangan diri adalah proses sosial dimana perasaan seseorang dipengaruhi oleh bagaimana orang lain berinteraksi dengan individu.

Berdasarkan penjelasan dari temuan penelitian ini, maka terdapat pula keterbatasan penelitian yaitu, fokus penulis adalah pada perilaku presentasi diri 
remaja di media Instagram, namun dari penelitian ini umpan balik ( feedback) dari penonton juga sangat menonjol. Sehingga dapat pula dikaji lebih lanjut mengenai respon dari penonton terhadap presentasi diri. Kemudian presentasi diri berlangsung secara online dan offline, dalam penelitian ini hanya berfokus pada presentasi online. Seorang remaja dapat menggunakan lebih dari satu situs jejaring sosial untuk melakukan presentasi diri, setiap situs jejaring sosial mempunyai konteks yang berbeda-beda yang dapat mempengaruhi perkembangan perilaku remaja. Maka penelitian dimasa depan harus mengevaluasi dan mengkaji lebih lanjut platform presentasi diri secara offline dan online yang berhubungan secara berbeda dengan presentasi diri dan hubungan interpersonal kaum remaja.

\section{Simpulan}

Perilaku presentasi diri seorang remaja pada media sosial Instagram ditunjukkan untuk membentuk harga diri mereka yang lebih tinggi. Pada dasarnya seorang remaja ingin diakui keberadaan mereka dihadapan khalayak luas, kemudian mereka berusaha menampilkan diri mereka secara luas dan mendalam, dengan berusaha menunjukkan citra positif dalam diri mereka.

Perbedaan penelitian ini dengan penelitian sebelumnya adalah, dalam temuan penelitian ini bahwa remaja yang melakukan presentasi diri berusaha untuk membangun konsep diri mereka kemudian diperluas untuk mendapatkan umpan balik ( feedback ) dari orang lain untuk menciptakan harga diri mereka. jadi tujuan remaja melakukan presentasi diri adalah untuk menciptakan kembali harga diri mereka di hadapan khalayak. Sedangkan penelitian yang dilakukan Yang dan Brown (2016), membuktikan jika presentasi diri adalah proses dinamis, bahwa seorang mahasiswa baru kurang menjaga presentasi diri mereka diruang online setelah menghabiskan waktu mereka di lingkungan baru. Mereka berusaha untuk mengungkapkan kembali sisi diri mereka dengan beragam aspek umpan balik yang mereka peroleh. Jadi dalam penelitian tersebut, umpan balik ( feedback) yang didapatkan seorang individu akan membantu mereka untuk pengembangan diri mereka di media sosia.

Keterbatasan dalam penelitian ini yaitu, bahwa peneliti hanya sebatas meneliti perilaku presentasi diri pada media sosial Instagram, peneliti tidak membatasi presentasi diri diruang online dan offline. Penelitian selanjutnya dapat meneliti ada tidaknya perbedaan antara online dan offline, atau dapat juga mencari perbedaan presentasi diri di media sosial antara remaja laki-laki dengan perempuan.

\section{Ucapan Terima Kasih}

Peneliti ingin mengucapkan banyak terimakasih kepada pihak-pihak yang telah membantu dalam menyelesaikan penelitian ini. Diantaranya kepada: (1) Ibu Dian Purworini, MM. Selaku pembimbing dalam menyelesaikan penelitian ini. (2) Bapak Joko Sumarsono, selaku humas SMA Negeri Mojogedang. (3) Seluruh siswa SMA Negeri Mojogedang yang telah bersedia berpartisipasi dalam menyelesaikan penelitian. (4) Yusnita Rani, sahabat saya yang senantiasa 
membantu dan menemani saya dalam melakukan penelitian. (5) Serta yang terpenting kedua orang tua yang telah mendanai penelitian ini dan selalu mendukung penuh.

\section{Daftar Pustaka}

Al-kandari, A., Melkote, S. R., \& Sharif, A. (2016). Needs and Motives of Instagram Users that Predict Self-disclosure Use : A Case Study of Young Adults in Kuwait. https://doi.org/10.1177/0973258616644808

APJII. (2016). Data Pengguna Internet Indonesia tahun 2016. Retrieved from http://isparmo.web.id/2016/11/21/data-statistik-pengguna-internetindonesia-2016/

Bullingham, L., \& Vasconcelos, A. C. (2013). "The presentation of self in the online world": Goffman and the study of online identities. Journal of Information Science, 39(1), 101-112. https://doi.org/10.1177/0165551512470051

Fajarini, A. (2014). Demi Foto Selfie, Triana Rela Operasi Plastik. Okezone.com. Retrieved from https://news.okezone.com/read/2014/04/25/214/975995/demi-foto-selfietriana-rela-operasi-plastik

Fardouly, J., Willburger, B. K., \& Vertanian, L. R. (2017). Instagram use and young women's body image concerns and self-objectification: Testing mediational pathways. https://doi.org/10.1177/1461444817694499

Fullwood, C., James, B. M., \& Chen-wilson, C. J. (2016). Self-Concept Clarity and Online, 1-6. https://doi.org/10.1089/cyber.2015.0623

Gangi, P. M. Di, \& Wasko, M. (2016). Social Media Engagement Theory: Exploring the Influence of User Engagement on Social Media Usage, 28, 53-73.

Goffman, E. (1956). The presentation of self In Everyday Life.

Gunawan, R. (2014). Siswi SMP Tewas Saat Selfie. liputan6.com. Retrieved from http://global.liputan6.com/read/2073410/siswi-smp-tewas-saat-selfie

Kinanti, S. P., \& Putri, B. P. (2017). Pengaruh Media Sosial Instagram @Zapcoid Terhadap Brand Equity Zap Clinic. Jurnal Komunikasi, Vol. 9,.No. 1, 5364. Terarsip di: https://journal.untar.ac.id/index.php/komunikasi/article/view/164/643

Kriantono, R. (2006). Teknik Praktis Riset Komunikasi. Jakarta: Kencana Prenadamedia Group.

Michikyan, M., Dennis, J., \& Subrahmanyam, K. (2015). Can You Guess Who I Am? Real, Ideal, and False Self-Presentation on Facebook Among Emerging Adults, 3(1), 55-64. https://doi.org/10.1177/2167696814532442

Permata, E. H. (2017). Instagram Dan Presentasi Diri (Analisis Kuantitatif Hubungan Penggunaan Media Sosial Instagram Dengan Presentasi Diri Mahasiswa Ilmu Komunikasi UNTIRTA Angkatan 2013-2015).

Purworini, D. (2014). Model Informasi Publik Di Era Media Sosial: Kajian Grounded Teori Di Pemda Sukoharjo. KomuniTi,Vol. VI, No. 1. 
Alfi Damayanti Sari Nastiti, Dian Purworini : Pembentukan Harga Diri: Analisis Presentasi Diri

https://publikasiilmiah.ums.ac.id/bitstream/handle/11617/4494/8_Dian\%2 OPurworini.pdf? sequence $=1$

Sherman, L. E., Payton, A. A., Hernandez, L. M., Greenfield, P. M., \& Dapretto, M. (2016). The Power of the Like in Adolescence: Effects of Peer Influence on Neural and Behavioral Responses to Social Media, 1-9. https://doi.org/10.1177/0956797616645673

Vogel, E. A., \& Rose, J. P. (2016). Self-reflection and interpersonal connection: Making the most of self- presentation on social media. (October). https://doi.org/10.1037/tps0000076

Widianto, W. (2015). Ini Foto Selfie Maut yang Menewaskan Seorang Remaja di Madiun. tribun jogja. Retrieved from http://www.tribunnews.com/regional/2015/02/23/ini-foto-selfie-mautyang-menewaskan-seorang-remaja-di-madiun

Woodward, T. S., \& Hunter, M. A. (2015). Estimation of Unattenuated Factor Loadings, 24(4), 384-397.

Yang, C., \& Brown, B. B. (2016). Online Self-Presentation on Facebook and Self Development During the College Transition. Journal of Youth and Adolescence, 45(2), 402-416. https://doi.org/10.1007/s10964-015-0385-y

Yusuf, O. (2014). Gagal "Selfie", Remaja Hampir Bunuh Diri. Compas.com. Retrieved from http://tekno.kompas.com/read/2014/03/24/1751335/gagal.selfie.remaja.ha mpir.bunuh.diri

Zarghooni, S. (2007). A Study of Self-presentation in Light of Facebook. Institute of Psychology, University of Oslo. Retrieved from https://zarghooni.files.wordpress.com/2011/09/zarghooni-2007selfpresentation_on_facebook.pdf 